\title{
Maternal Betaine Supplementation throughout Gestation and Lactation Modifies Hepatic Cholesterol Metabolic Genes in Weaning Piglets via AMPK/LXR-Mediated Pathway and Histone Modification
}

\author{
Demin Cai ${ }^{1,+}$, Mengjie Yuan ${ }^{1,+}$, Haoyu Liu ${ }^{2,+}$, Shifeng Pan ${ }^{1}$, Wenqiang Ma ${ }^{1}$, Jian Hong ${ }^{1}$ and \\ Ruqian Zhao ${ }^{1,3, *}$ \\ 1 Key Laboratory of Animal Physiology \& Biochemistry, Nanjing Agricultural University, Nanjing 210095, \\ China; yzu.jsnj.ice@163.com (D.C.); senrutoday@163.com (M.Y.); pan.sf@163.com (S.P.); \\ wq8110@126.com (W.M.); jian_hong602@sina.com (J.H.) \\ 2 Department of Medical Cell Biology, Uppsala University, Uppsala SE-75123, Sweden; haoyu.liu@mcb.uu.se \\ 3 Jiangsu Collaborative Innovation Center of Meat Production and Processing, Quality and Safety Control, \\ Nanjing 210095, China \\ * Correspondence: zhao.ruqian@gmail.com; Tel.: +86-25-84395047 \\ + These authors contributed equally to this study.
}

Received: 15 August 2016; Accepted: 2 October 2016; Published: 18 October 2016

\begin{abstract}
Betaine serves as an animal and human nutrient which has been heavily investigated in glucose and lipid metabolic regulation, yet the underlying mechanisms are still elusive. In this study, feeding sows with betaine-supplemented diets during pregnancy and lactation increased cholesterol content and low-density lipoprotein receptor (LDLR) and scavenger receptor class B type I (SR-BI) gene expression, but decreasing bile acids content and cholesterol-7a-hydroxylase (CYP7a1) expression in the liver of weaning piglets. This was associated with the significantly elevated serum betaine and methionine levels and hepatic $S$-adenosylmethionine (SAM) and $S$-adenosylhomocysteine $(\mathrm{SAH})$ content. Concurrently, the hepatic nuclear transcription factor liver $\mathrm{X}$ receptor LXR was downregulated along with activated signal protein AMP-activated protein kinase (AMPK). Moreover, a chromatin immunoprecipitation assay showed lower LXR binding on CYP7a1 gene promoter and more enriched activation histone marker H3K4me3 on LDLR and SR-BI promoters. These results suggest that gestational and lactational betaine supplementation modulates hepatic gene expression involved in cholesterol metabolism via an AMPK/LXR pathway and histone modification in the weaning offspring.
\end{abstract}

Keywords: betaine; AMPK; LXR; cholesterol metabolism; maternal diet; piglets

\section{Introduction}

Betaine, also called TMG (trimethylglycine), is a natural component existing in all living organisms which can be obtained from diet or be synthesized from choline in mammals [1]. Both clinical investigations and experimental studies demonstrate its vital function of hepatoprotection in liver metabolic diseases, including nonalcoholic liver disease and bile acid-induced liver injury [2-4]. Recent studies have shown that hepatic lipid metabolic abnormality in the postnatal period is tightly linked to higher risk of later development of chronic metabolic diseases [5]. Therefore, whether betaine is a prophylactic strategy to decrease the susceptibility to metabolic illnesses in adulthood through controlling cholesterol metabolism in the liver during early life remains to be clarified. 
Hepatic cholesterol homeostasis is maintained by series of biochemical reactions including cholesterol synthesis, uptake, and efflux [6]. HMGCR (3-hydroxy-3-methylglutaryl-CoA reductase) is the primary enzyme regulating cholesterol biosynthesis [7]. During transportation, excessive hepatic cholesterol is transported into the serum via low-density lipoprotein receptor (LDLR) [8] whilst the reverse transportation depends on scavenger receptor class B type I (SR-BI) [9]. Furthermore, the conversion from cholesterol to bile acid is carried out by cholesterol-7 $\alpha$-hydroxylase (CYP7a1) and cholesterol-27a-hydroxylase (CYP27a1) [10]. Because of the critical action of nuclear receptors (NRs) on the regulation of metabolic genes, cholesterol metabolic genes expressions are shown to be modulated by NRs in numerous literatures [11-13]. Liver X receptor (LXR) plays a crucial role in the regulation of cholesterol efflux and influx by inhibiting the LDLR pathway or reducing the expression of SR-BI [14,15]. LXR is also found to bind on the promoter of CYP7a1 gene [16] and then controls hepatic bile acids formation directly or interacts with peroxisome proliferator-activated receptor alpha $(P P A R \alpha)$ [17]. In contrast, farnesoid X receptor (FXR) has been well demonstrated to be a bile acid sensor and predominant regulator of the CYP7a1 gene $[18,19]$. However, it is still elusive whether nuclear receptors regulate the hepatic cholesterol metabolic gene in vivo during the early stage of life.

Betaine participating in epigenetic regulation for gene expression has been documented in a number of studies, and is correlated with methionine metabolism [1]. In this metabolic cycle, methionine, in turn, is converted to $S$-adenosylmethionine (SAM), $S$-adenosylhomocysteine (SAH) and homocysteine using enzymes methionine adenosyl transferase (MAT), glycine N-methyltransferase (GNMT), and S-adenosylhomocysteine hydrolase (AHCY), respectively [20]. Finally, homocysteine is remethylated to methionine catalyzed by betaine-homocysteine methyltransferase (BHMT) to complete this metabolic cycle [21]. Notably, SAM is critical for epigenetic regulation because it supports methyl groups for DNA and protein methylation. Especially, in the liver, the ratio of SAM to SAH is a pivotal indicator to assess the methylated status of global and specific genes [22]. It is worthwhile to mention that AMP-activated protein kinase (AMPK), a SAM sensor, is able to bind SAM directly [21] and is a kinase upstream in the LXR pathway, so can inactivate LXR-mediated gene transcription [23]. Moreover, Dahlhoff et al. provides the evidence that methyl donors, including betaine and methionine supplementation, enhance SAM formation and then activate AMPK-signaling pathway in mice [24].

Therefore, we hypothesized that maternal dietary supplementation of betaine may affect cholesterol metabolic genes through epigenetic mechanisms and nuclear-receptor-mediated signal pathways in the liver of offspring. It would be interesting to eventually use betaine supplementation as a prophylactic strategy to decrease the susceptibility to metabolic illnesses in adulthood.

\section{Materials and Methods}

\subsection{Animals and Sampling}

Sixteen cross-bred Landrace X Yorkshire sows (second parity) were inseminated artificially with a mixture of Duroc semen samples obtained from two littermate boars when estrus occurred. One week later, 8 sows were randomly assigned to the treated group (Bet), and the remaining 8 were assigned to the control group (Con). Sows in control group received basal diet whilst betaine group were fed betaine-supplemented $(3 \mathrm{~g} / \mathrm{kg})$ diet during gestation and lactation $(98 \%$ pure betaine hydrochlorides; SKYSTONE FEED CO., Ltd., Yixing. Jiangsu, China). The diet composition is shown in Table 1.

The housing barn had a controlled environmental system with constant temperature at $25^{\circ} \mathrm{C}$ and $50 \%$ humidity on a $12 \mathrm{~h} / 12 \mathrm{~h}$ light/dark cycle. Feed was offered at 05:00, 10:00, and 17:00 per day with free access to water. Twenty-four hours after farrowing, litter size was adjusted to 7-8 piglets per litter in the same group. After 35 days of age, one piglet per litter close to the mean body weight of the litter was killed for sampling. Serum samples were collected immediately and stored at $-80^{\circ} \mathrm{C}$ and liver samples (no gall bladder) were taken within $20 \mathrm{~min}$ postmortem then snap-frozen in liquid nitrogen and stored at $-80^{\circ} \mathrm{C}$ for further analysis. 
The animal experiment was undertaken with the project number 2012CB124703, Animal Ethics Committee of Nanjing Agricultural University, following the "Guidelines on Ethical Treatment of Experimental Animals" (2006) No. 398 set by the Ministry of Science and Technology, China.

Table 1. Composition and nutrient content of the experimental diet.

\begin{tabular}{ccccc}
\hline & \multicolumn{2}{c}{ Gestation } & \multicolumn{2}{c}{ Lactation } \\
\cline { 2 - 5 } & Con & Bet & Con & Bet \\
\hline Ingredient, $\mathrm{g} / \mathrm{kg}$ & & & & \\
Corn & 370 & 370 & 332.5 & 332.5 \\
Wheat & 300 & 300 & 100 & 100 \\
Bran & 80 & 80 & 50 & 50 \\
Soybean meal & 170 & 170 & 253 & 253 \\
Maize starch & 0 & 0 & 150 & 150 \\
Lignocelluloses & 30 & 30 & 0 & 0 \\
CaHPO4 & 20 & 20 & 20 & 20 \\
Soybean oil & 8 & 8 & 34.5 & 34.5 \\
Fish meal & 0 & 0 & 40 & 40 \\
Premix * & 20 & 20 & 20 & 20 \\
Betaine & 0 & 3 & 0 & 3 \\
Digestible energy, MJ $/ \mathrm{kg}$ & 13.1 & 13.1 & 14.39 & 14.39 \\
Calculated composition \% & & & & \\
Crude protein, \% & 15 & 15 & 18 & 18 \\
Crude fiber, \% & 4.5 & 4.5 & 2.3 & 2.3 \\
Calcium, \% & 0.84 & 0.84 & 0.9 & 0.9 \\
Phosphorous, \% & 0.65 & 0.65 & 0.7 & 0.7 \\
\hline
\end{tabular}

* The premix contains (per kilogram): Vitamin A: 240,000 IU; vitamin D-3: 60,000 IU; vitamin E: 720 IU; vitamin K-3: $30 \mathrm{mg}$; vitamin B-1: $30 \mathrm{mg}$; vitamin B-2: $120 \mathrm{mg}$; vitamin B-6: $60 \mathrm{mg}$; vitamin B-12: $360 \mathrm{mg}$; niacin: $600 \mathrm{mg}$; pantothenic acid: $300 \mathrm{mg}$; folic acid: $6 \mathrm{mg}$; manganese sulphate: $1.0 \mathrm{~g}$; zinc oxide: $2.5 \mathrm{~g}$; ferrous sulphate: $4.0 \mathrm{~g}$; copper sulphate: $4.0 \mathrm{~g}$; sodium selenite: $6 \mathrm{mg}$; calcium: $150 \mathrm{~g}$; phosphorus: $15 \mathrm{~g}$; sodium chloride: $40 \mathrm{~g}$.

\subsection{Measurement of Cholesterol and Bile Acid Concentrations}

The content of total cholesterol and triglycerides (TG) in serum was measured using commercial assay kit (E1005 and E1003 respectively; Applygen Technologies, Inc. Beijing, China). Concentrations of LDL cholesterol (LDLC) and high-density lipoprotein cholesterol (HDLC) in serum were measured with respective assay kits (006340 and 006328, Beijing BHKT Clinical Reagent Co., Ltd., Beijing, China). The cholesterol and TG in liver was determined according to the instruction of a tissue commercial assay kit (E1015 and E1013 respectively; Applygen Technologies, Inc. Beijing, China). Hepatic and serum bile acid content was detected by enzymatic colorimetric methods according to a commercial bile acid assay kit (E003; Nanjing Jiancheng Bioengineering Institute, Nanjing, Jiangsu, China).

\subsection{Determination of Serum Betaine Content and Hepatic S-Adenosyl Methionine and S-Adenosyl Homocysteine Concentrations}

Serum betaine concentrations were analyzed in China National Feed Quality Control Center, Chinese Academy of Agricultural Sciences, Beijing, China by liquid chromatography (Aglient 1200, Aglient Techologies. Santa Clara, California, USA)—MS (API 5000TM; AB Foster City, California, USA) system. Hepatic SAM and SAH concentrations were determined by Quantitative Porcine Competitive ELISA kits (S200FC and S198FC respectively; Hermes Criterion Biotechnology, Vancouver, BC, Canada) following the manufacturer's protocol.

\subsection{Serum Hormones and Amino Acids Profile}

Serum concentrations of insulin, glucagon, and cortisol were measured with respective commercial RIA kits (No. F01PZB, F03PZB and D10PZB Beijing North Institute of Biological Technology, Beijing, China) with $10 \%$ and $15 \%$ of intra- and inter-assay variations. 
Serum samples for measuring the free amino acid concentration were prepared according to a previous publication [21]. Serum concentrations of free amino acids were determined with an automatic amino acid analyzer (L-8900, Hitachi, Japan) in duplicate. The intra- and inter-assay coefficients of variation were $3 \%$ and $6 \%$, respectively.

\subsection{Real-Time PCR for mRNA Quantification}

Total RNA was extracted from the liver samples $(200 \mathrm{mg})$. The frozen tissue sections were homogenized in TRIzol Reagent (Invitrogen, Santa Rosa, USA) according to the manufacturer's protocol. Approximately $2 \mu \mathrm{g}$ RNA was reverse transcribed into cDNA with the random hexamer primers (Promega, Madison USA) and reverse transcription products were stored at $-20{ }^{\circ} \mathrm{C}$. The quantitative analysis of gene expression was carried out on an Mx3000P (Stratagene, Santa Rosa, USA) real-time PCR system with $2 \mu \mathrm{L}$ diluted cDNA (1:25). Stable reference gene peptidylprolyl isomerase A (PPIA) was selected for the normalization of target gene expression level. The final result was expressed as relative expression by comparing the amount of target gene to PPIA. All primers were synthesized by Generay Biotech and listed in Table 2 .

Table 2. Nucleotide sequences of specific primers.

\begin{tabular}{|c|c|c|c|}
\hline Target Genes & Sequences $\left(5^{\prime}\right.$ to $\left.3^{\prime}\right)$ & & GenBank No. \\
\hline \multicolumn{4}{|c|}{ mRNA expression } \\
\hline$A H C Y$ & F: gtggtggtgtgtggctacgg & R: gcagagcacagatggggtca & NM_001201381.1 \\
\hline$A P O E$ & F: gtgcgcaaccgcttggtgctct & R: gacgagccgcttgcgcacgtt & NM_214308.1 \\
\hline CYP7a1 & F: tagcaggcttcccgattc & R: ctgaccagttccgagatgtg & AK230868.1 \\
\hline CYP27a1 & F: tgtggctcgcatcgttc & $\mathrm{R}:$ tcacctggcagctcctt & EF625352.1 \\
\hline GNMT & F: acaaagatgtgccca & R: gtgctgaggatgtggtcgta & NM_001110419.2 \\
\hline MAT & F:ctgacagtcctgtcttgggagc & R: gccagagtgattctttgatgcc & NC__010458.3 \\
\hline BHMT & F:gaggctgtgtgggcagttgaag & R: acaatggatgctcctgcctttacc & NM_001200042.1 \\
\hline DNMT1 & F: tcagggaccacactgtaag & R: gctgcagccattcttcttgt & DQ060156.1 \\
\hline DNMT3a & F: ggctcttctttgagttctaccg & R: gcgagatgtccctcttgtca & DQ785811.1 \\
\hline DNMT3b & F: tgaagagtccatcgctgttg & R: caatcaccaggtcaaaggg & NM_001162404.1 \\
\hline FXR & F: cggagaagcattacca & R: aagcattcagccaaca & XM 001928800.2 \\
\hline HMGCR & F: caggctgaagtaagggaga & R: cacgaagtaggtggcga & DQ432054.1 \\
\hline LDLR & F: actgctcatcctcc tctt & R: ttccgtggtcttctggta & AF065990.1 \\
\hline$L X R$ & F: atttccaggagtgccgtctt & R: cttgccgcttcagtttctt & AB254406.1 \\
\hline LCAT & F: ggctggtggaagaaatgc & R: gggttggcgtagtaagaaata & NM_001164856.1 \\
\hline PPAR $\alpha$ & F:actgaacatcgaatgtagaatct & R: tctgaatcttacagctccgatc & NM_001044526.1 \\
\hline PPIA & F: gactgagtggttggatgg & R: tgatcttcttgctggtctt & NC__010460.3 \\
\hline$S R-B I$ & F:tcaagcagcaggtcctcaag & R: cttgtgcctgaactccetgta & NM_213967.1 \\
\hline \multicolumn{4}{|l|}{ ChIP assay } \\
\hline$L D L R$ fragment & F: tcagaggagaggaagtggct & R: atccagcgctcagatgaat & \\
\hline$S R-B I$ fragment & F: gttgcatgaatgagcctact & R: cgtgaattccataggtaaca & \\
\hline CYP7a1 fragment & F: tgtctccacgggegtaccaga & R: gtggcaatatacagacatct & \\
\hline
\end{tabular}

\subsection{Western Blotting for Protein Quantification}

Total protein was extracted from $200 \mathrm{mg}$ frozen liver sample as described before. Briefly, samples were homogenized with RIPA buffer (No. 89900, Thermo, Santa Rosa, USA), and incubated for 20 min on ice, followed by centrifugation for $10 \mathrm{~min}$ at $12,000 \mathrm{rpm}$ at $4{ }^{\circ} \mathrm{C}$. The protein content of each sample was quantified with a Pierce BCA Protein Assay kit (No. 23225, Thermo, Santa Rosa, USA). Western blot analysis for target protein was carried out depending on recommended instruments provided by the manufacturers. $\beta$-Actin and GAPDH (glyceraldehyde-3-phosphate dehydrogenase) were used as references for total protein, while $\mathrm{H} 1$ was used as a reference for nuclear protein in the Western blot analysis. All antibodies used are listed in Table 3. 
Table 3. Antibodies for this experiment.

\begin{tabular}{|c|c|c|c|c|}
\hline Antibodies & MW & Species & Source & Catalogue No. \\
\hline \multicolumn{5}{|c|}{ Western Blotting } \\
\hline GNMT & $33 \mathrm{kd}$ & Rabbit & proteintech $^{\mathrm{TM}}$ & 18790-1-AP \\
\hline BHMT & $50 \mathrm{kd}$ & Rabbit & proteintech $^{\mathrm{TM}}$ & 15965-1-AP \\
\hline MAT & $38 \mathrm{kd}$ & Rabbit & proteintech $^{\mathrm{TM}}$ & 15952-1-AP \\
\hline AHCY & $60 \mathrm{kd}$ & Rabbit & proteintech $^{\mathrm{TM}}$ & 10658-3-AP \\
\hline DNMT1 & $184 \mathrm{kd}$ & Rabbit & Santa Cruz & sc-20701 \\
\hline DNMT3a & $102 \mathrm{kd}$ & Rabbit & Bioworld & BS6587 \\
\hline DNMT3b & $96 \mathrm{kd}$ & Rabbit & Bioworld & BS2572 \\
\hline HMGCR & $97 \mathrm{kd}$ & Rabbit & Bioworld & BS6625 \\
\hline LDLR & $160 \mathrm{kd}$ & Rabbit & proteintech $^{\mathrm{TM}}$ & 10785-1-AP \\
\hline SR-BI & $82 \mathrm{kd}$ & Rabbit & Abcam & ab137829 \\
\hline CYP7a1 & $57 \mathrm{kd}$ & Rabbit & Abcam & ab79847 \\
\hline CYP27a1 & $60 \mathrm{kd}$ & Rabbit & proteintech $^{\mathrm{TM}}$ & 14739-1-AP \\
\hline AMPK & $65 \mathrm{kd}$ & Mouse & santa cruz & sc-25792 \\
\hline P-AMPKa1/2 & $65 \mathrm{kd}$ & Rabbit & santa cruz & sc-33524 \\
\hline FXR & $69 \mathrm{kd}$ & Goat & santa cruz & sc-1205 \\
\hline $\operatorname{LXR} \alpha / \beta$ & $49 \mathrm{kd}$ & Rabbit & santa cruz & sc-13068 \\
\hline $\operatorname{PPAR} \alpha$ & $55 \mathrm{kd}$ & Rabbit & santa cruz & sc-9000 \\
\hline GAPDH & $36 \mathrm{kd}$ & Mouse & KangChen Bio-tech & KC-5G4 \\
\hline$\beta$-actin & $42 \mathrm{kd}$ & Mouse & KangChen Bio-tech & KC-5A08 \\
\hline $\mathrm{H} 1$ & $30 \mathrm{kd}$ & Rabbit & Abcam & ab17584 \\
\hline
\end{tabular}

\subsection{Chromatin Immunoprecipitation}

Chromatin immunoprecipitation (ChIP) analysis was performed according to our previous publication [25]. Crude chromatin preparations were isolated from approximately $200 \mathrm{mg}$ frozen liver samples and were sonicated and precleared with salmon sperm DNA-treated protein G agarose beads $(40 \mu \mathrm{L}, 50 \%$ slurry, sc-2003, Santa Cruz Biotechnology, Santa Cruz, USA). The precleared chromatin products mixed with $2 \mu \mathrm{g}$ of specific primary antibody (H3, ab1791, Abcam, Cambridge, USA; H3K4me3, ab8580, Abcam; H3K27me3, 17-622, Millipore, Darmstadt, Germany) overnight at $4{ }^{\circ} \mathrm{C}$. We used normal rat IgG as a negative control. For capturing the immunoprecipitated chromatin complexes, we added protein $\mathrm{G}$ agarose beads again into the aforementioned mixture. Finally, we released DNA fragments from reverse cross-linking and quantified target gene fragments using with specific primers (Table 2).

\subsection{Statistical Analysis}

All data are presented as means \pm S.E.M. and were analyzed using independent two-tailed Student's $t$-test with SPSS 19.0 for Windows (SPSS, Inc. Armonk, USA). Since none of the detected parameters showed sex disparity, we pooled male and female together. Values of mRNA and protein are presented as the fold change relative to the mean value of the control group. For all analyses, $p<0.05$ was considered significant.

\section{Results}

\subsection{Serum Concentrations of Metabolites in Weaning Piglets}

As shown in Table 4, maternal betaine supplementation did not change body weight or liver weight in the weaning piglets. However, serum levels of betaine and LDLC/HDLC, together with methionine and phenylalanine, were found to be higher in the betaine-exposed piglets compared to that in the control group $(p<0.05)$. 
Table 4. Body weight, liver weight, and serum concentrations of metabolites in weaning piglets.

\begin{tabular}{ccc}
\hline Variables & Control $(n=8)$ & Betaine $(n=8)$ \\
\hline Body weight, $\mathrm{kg}$ & $7.27 \pm 0.31$ & $7.37 \pm 0.40$ \\
Liver weight, $\mathrm{g}$ & $183.7 \pm 14.9$ & $178.0 \pm 10.5$ \\
Biochemical metabolites & & \\
Serum betaine, $\mu \mathrm{mol} / \mathrm{L}$ & $1.49 \pm 0.11$ & $3.55 \pm 0.31^{*}$ \\
TG, mmol/L & $1.40 \pm 0.15$ & $1.11 \pm 0.14$ \\
TCH, $\mathrm{mmol} / \mathrm{L}$ & $4.43 \pm 0.38$ & $4.88 \pm 0.34$ \\
TBA, $\mu \mathrm{mol} / \mathrm{L}$ & $58.4 \pm 4.12$ & $4.88 \pm 0.34$ \\
$\mathrm{LDLC}, \mathrm{mmol} / \mathrm{L}$ & $1.94 \pm 0.19$ & $2.55 \pm 0.20$ \\
$\mathrm{HDLC}, \mathrm{mmol} / \mathrm{L}$ & $2.00 \pm 0.14$ & $1.81 \pm 0.11$ \\
LDLC/ $\mathrm{HDLC}$ & $1.00 \pm 0.09$ & $1.47 \pm 0.10^{*}$ \\
Amino acids & & \\
Isoleucine $(\mu \mathrm{mol} / \mathrm{L})$ & $139 \pm 13.5$ & $148 \pm 15.2$ \\
Leucine $(\mu \mathrm{mol} / \mathrm{L})$ & $279 \pm 23.8$ & $309 \pm 18.3$ \\
Lysine $(\mu \mathrm{mol} / \mathrm{L})$ & $235 \pm 10.2$ & $259 \pm 41.9$ \\
Methionine $(\mu \mathrm{mol} / \mathrm{L})$ & $46.1 \pm 6.34$ & $82.3 \pm 7.16^{*}$ \\
Phenylalanine $(\mu \mathrm{mol} / \mathrm{L})$ & $90.4 \pm 5.88$ & $128 \pm 10.9^{*}$ \\
Tyrosine $(\mu \mathrm{mol} / \mathrm{L})$ & $299 \pm 35.0$ & $296 \pm 44.5$ \\
\hline
\end{tabular}

Values are means $\pm \mathrm{SEM}, n=8$. Different from control, ${ }^{*} p<0.05$.

\subsection{Cholesterol Metabolism in Weaning Piglets}

Maternal betaine supplementation significantly increased hepatic cholesterol (Figure 1B) $(p<0.05)$ and decreased bile acids content (Figure 1C) $(p<0.05)$, which is associated with upregulated LDLR and SR-BI expression, and downregulated CYP7a1 expression, both at mRNA and protein level in the weaning piglets (Figure 1D-F, $p<0.05$ ).
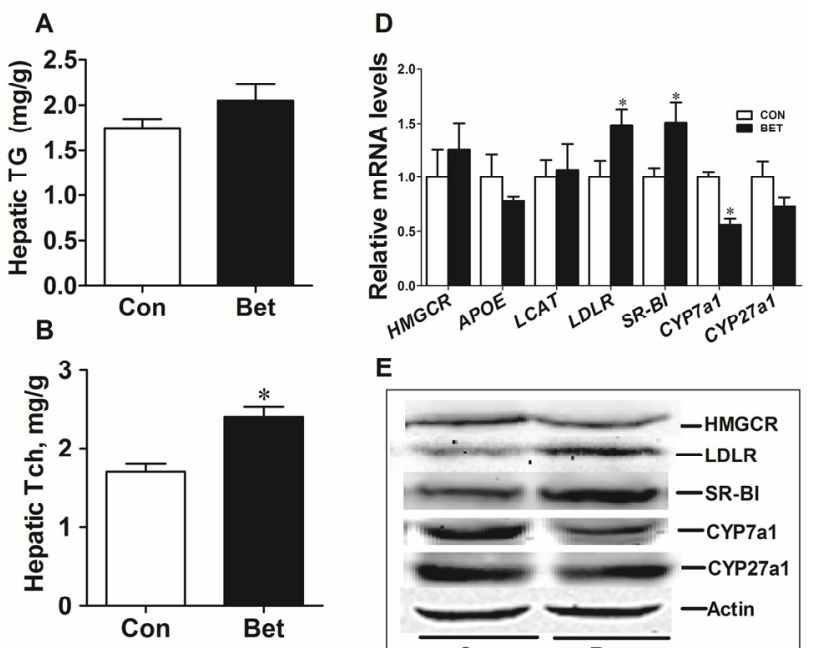

E
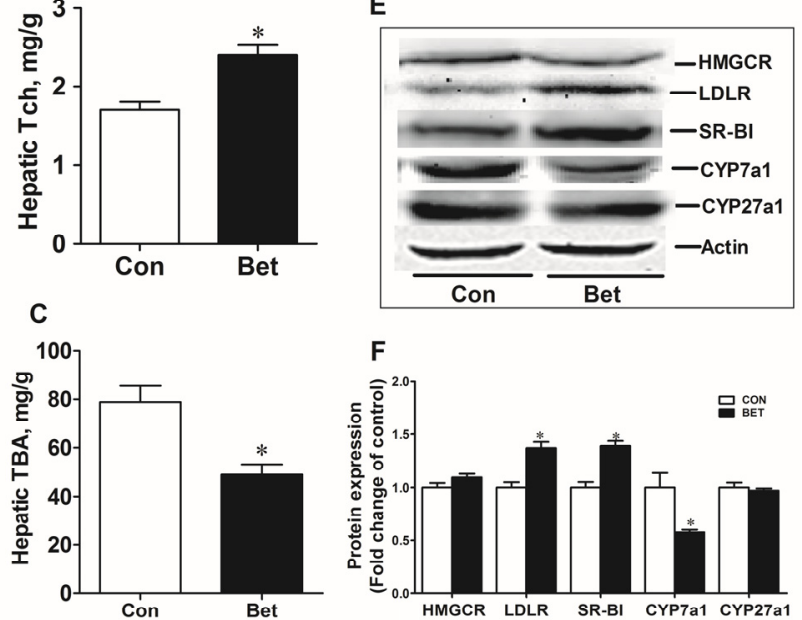

Figure 1. Hepatic triglycerides (A); total cholesterol (B); and total bile acids (C) of the offspring piglets at weaning; hepatic mRNA level (D); Western blotting analysis and graphic summary (E,F) of cholesterol metabolic genes in the liver of weaning piglets. Values are means $\pm \mathrm{SEM}, n=8$. Different from control, ${ }^{*} p<0.05$. 


\subsection{Methionine Metabolism in Weaning Piglets}

Maternal betaine supplementation significantly increased hepatic SAM (Figure 2A, $p<0.05$ ) and SAH content (Figure 2B, $p<0.05$ ), yet the ratio of SAM to SAH was not altered in piglets (Figure $2 \mathrm{C}$ ). Although the key genes involved in methionine metabolism including BHMT, AHCY, and GNMT were downregulated at transcriptional level (Figure 2D, $p<0.05$ ), the protein expression of these enzymes was not changed (Figure 2E,F). Moreover, among these key methyltransferases, only DNA methyltransferase 3b (DNMT3b) was upregulated at protein level (Figure 2H,I, $p<0.05$ ), while DNMT1 and DNMT3a expressions were not changed either at mRNA (Figure 2G) or protein level (Figure 2H,I) in the liver of betaine-exposed piglets.
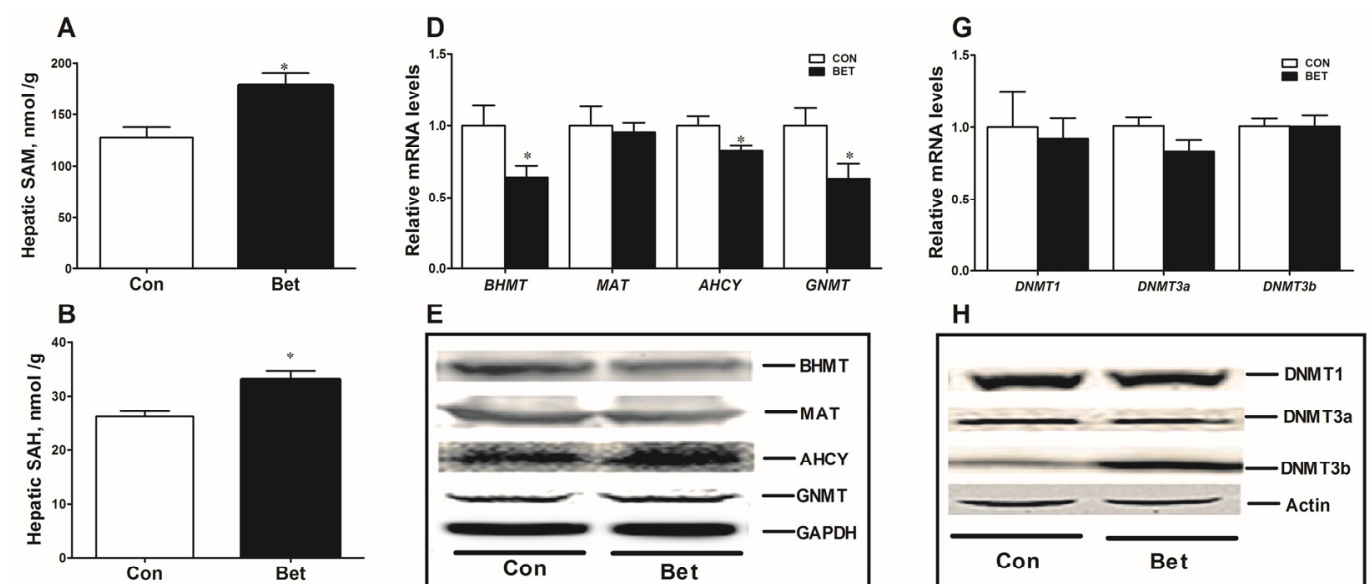

E
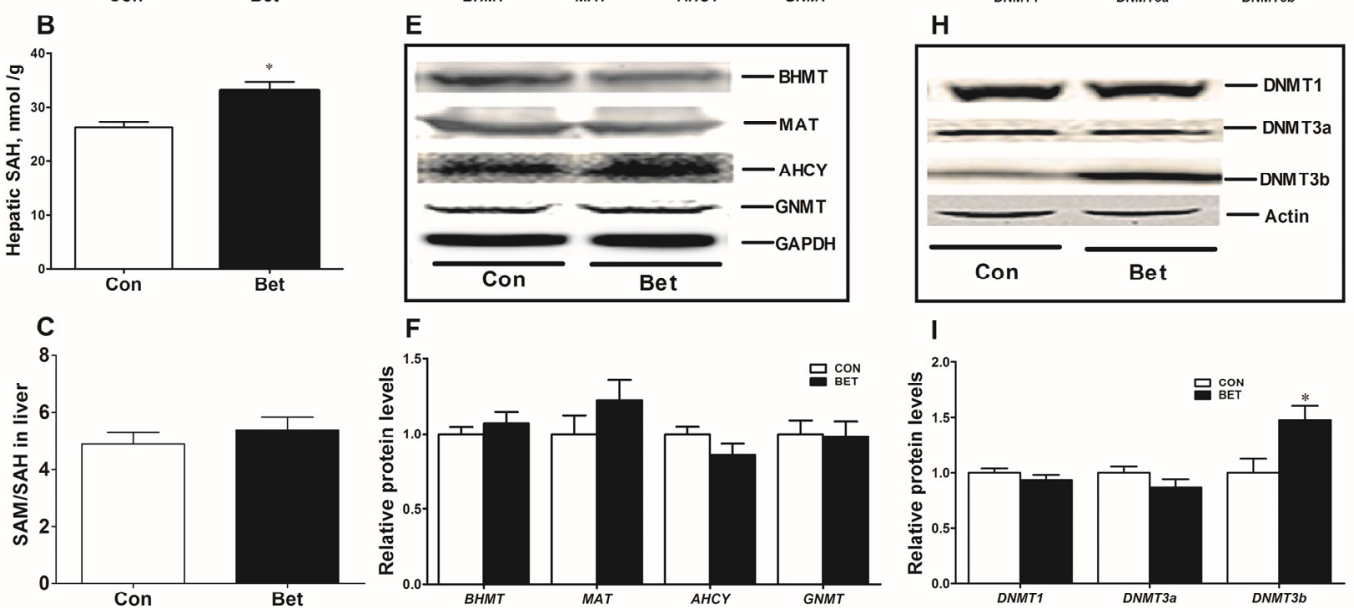

Figure 2. Concentration of hepatic $S$-adenosylmethionine (SAM) (A) and S-adenosylhomocysteine (SAH) (B); as well as the ratio of hepatic SAM to SAH (C) in weaning piglets; hepatic mRNA abundance (D); and Western blotting analysis plus graphic summary (E, F) of proteins expression involved in methionine metabolic cycle; DNA methyltransferases including DNMT1, DNMT3a, and DNMT3b expression at mRNA $(\mathbf{G})$ and protein level $(\mathbf{H}, \mathbf{I})$ in the liver of weaning piglets. Values are means \pm SEM, $n=8$. Different from control, ${ }^{*} p<0.05$.

\subsection{Transcriptional Regulation of Cholesterol Metabolic Genes}

Maternal betaine supplementation significantly reduced the mRNA level of hepatic nuclear transcription factors FXR, LXR, and PPAR $\alpha$ (Figure 3A, $p<0.05$ ), but only LXR protein content was downregulated (Figure 3B,C, $p<0.05$ ) in parallel with its mRNA. Phosphorylated-AMPK was found to be increased significantly at the protein level (Figure 3D,E, $p<0.05$ ). The ChIP assay was used to detect the LXR binding enrichment and histone modification on the changed cholesterol metabolic genes promoter. As illustrated in Figure 3F, the betaine-exposed piglets demonstrated lower LXR binding to the CYP7a1 gene promoter $(p<0.05)$, and significantly enriched histone activation marker, H3K4me3, on $L D L R$ and $S R-B I$ genes' promoters (Figure $3 \mathrm{G}, \mathrm{H}, p<0.05$ ). 


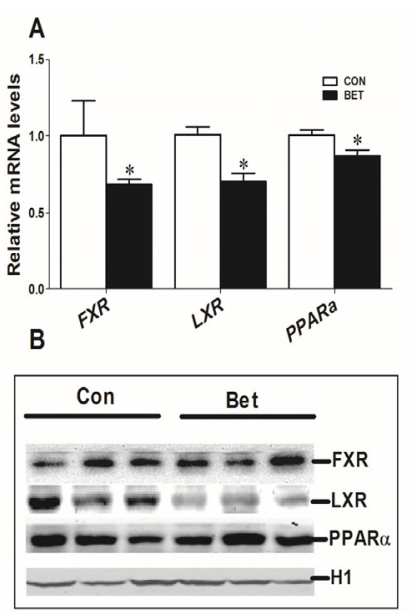

D

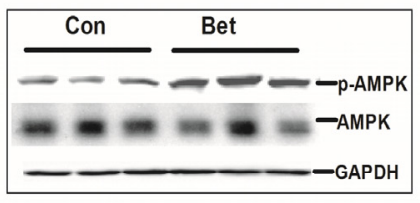

$E$
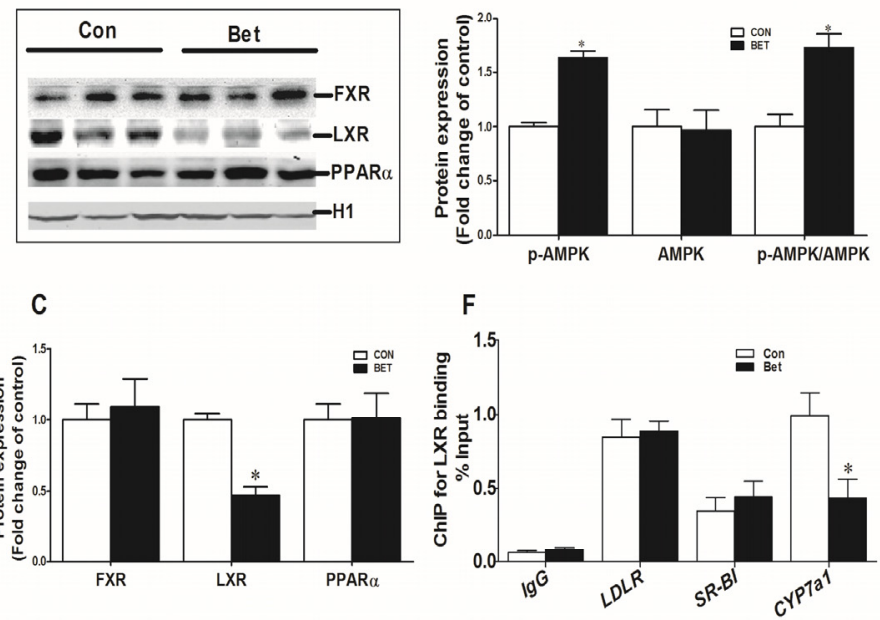

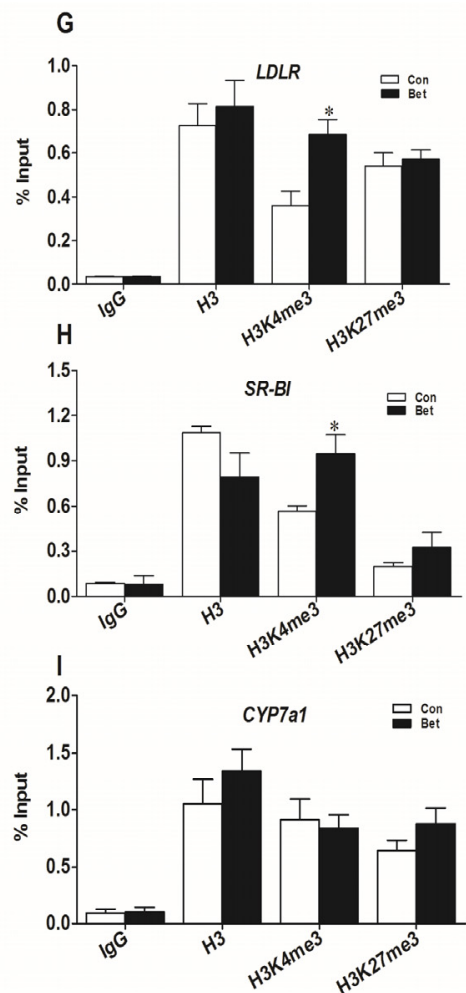

Figure 3. Hepatic mRNA abundance (A) and Western blotting analysis (B, C) of nuclear transcriptional factors farnesoid $X$ receptor (FXR), liver $X$ receptor (LXR), and peroxisome proliferator-activated receptor alpha $(\operatorname{PPAR} \alpha)$; (D, E) illustrates Western blotting analysis and graphic summary of signal protein AMP-activated protein kinase (AMPK) in the liver of weaning piglets. Chromatin immunoprecipitation (ChIP) analysis of LXR binding on low-density lipoprotein receptor (LDLR), scavenger receptor class B type I (SR-BI), and cholesterol-7 $\alpha$-hydroxylase (CYP7a1) genes' promoters (F); and respective ChIP analysis of histone modifications on $L D L R(\mathbf{G}) ; S R-B I(\mathbf{H})$; and CYP7a1 (I) genes' promoters in the liver of weaning piglets. Values are means $\pm \mathrm{SEM}, n=8$. Different from control, * $p<0.05$.

\section{Discussion}

It has been shown that mother-derived betaine can be accumulated in the fetus at a higher concentration than that in maternal circulation [26]. Moreover, dietary betaine supplementation in lactational sows significantly increases betaine content in the milk [27]. Here, we found that maternal betaine supplementation during gestation and lactation caused significant increase in serum betaine levels of the weaning offspring. In mammals, methionine is synthesized from the homocysteine using betaine as a substrate [28]. Serum methionine level is found to be increased following dietary betaine supplementation in human subjects [29]. In agreement with these findings, we detected elevated methionine concentration associated with higher betaine level in the serum of betaine-exposed piglets.

The effects of betaine on cholesterol homeostasis are controversial. Betaine supplementation in human subjects increased serum total cholesterol and LDLC concentrations [30,31]. On the contrary, dietary betaine supplementation was also reported to decrease the serum total cholesterol concentration in pigs [32]. A negative correlation between plasma betaine concentration and plasma concentrations of total cholesterol and LDLC was reported in an epidemiological research [33]. In the present study, betaine-exposed weaning offspring had $41.2 \%$ higher hepatic cholesterol and $62.5 \%$ lower hepatic bile acids content along with a significantly elevated serum LDLC/HDLC compared with the control groups. We suggest this is partly due to the reduced cholesterol transformation and increased cholesterol transportation. 
In line with $\mathrm{Hu}$ et al. finding that in vivo injection with betaine significantly increases hepatic cholesterol content and decreases hepatic CYP7a1 expression in newly hatched chicks [34], herein, piglets demonstrated obviously reduced hepatic CYP7a1 transcriptional and translational expression under maternal betaine supply. In this process, CYP7a1 transcription is predominantly regulated by the nuclear receptor FXR, which induces the small heterodimer partner (SHP) in liver that downregulates CYP7a1 expression [35].

LXR has been regarded as a dominant regulator of CYP7a1 transcription by Gupta et al. [36]. We provided the first evidence that LXR directly binds to porcine CYP7a1 gene and positively regulates CYP7a1 transcription by ChIP assay. Although betaine functions on LXR are still unknown, betaine promotes SAM formation by increasing methionine level through one-carbon metabolism [37]. It is reported that AMPK may bind SAM directly and acts as a direct SAM-sensor, thus methyl donation, including betaine and methionine supplementation, result in AMPK signaling pathway activation [24]. Again, AMPK has been demonstrated to be a kinase upstream of LXR, and the activated AMPK (phospho-AMPK) inhibits endogenous LXR ligand production, which then diminishes LXR expression and blocks LXR transcriptional regulation [23]. Thus the lower LXR expression and binding on CYP7a1 may, at least, be attributed to the activated AMPK and elevated SAM content in the liver of betaine-exposed piglets at weaning.

Methylation of DNA and chromatin histones by specific methyltransferases utilize SAM as the methyl donor [38] and hepatic SAM/SAH ratio is a critical indicator of cellular methylation reactions [22]. In our current data, hepatic SAM was significantly increased in piglets of betaine group, but the ratio of SAM to SAH had not changed. Similar to a preceding finding of Medici et al. [39], no significant alteration was observed for the expression of key enzymes involved in methionine metabolism or the methyltransferases. Thus, we excluded DNA methylation analysis for these changed cholesterol metabolic genes. However, we found more enrichment of histone-activated marker H3K4me3 on the LDLR and SR-BI genes' promoters, which is associated with enhanced gene transcription. It is noted that H3K4me3 is trimethylated by a SAM-dependent enzyme, SETD7 [40], and our previous study has demonstrated that maternal betaine diet increases SETD7 expression in the liver of offspring [41]. Therefore, in the present study, enhanced SAM content may greatly contribute to activate histone modification in the promoters of hepatic cholesterol metabolic genes in the betaine-exposed weaning piglets.

It is worthwhile to mention that methionine-homocysteine cycle is strongly regulated by feedback mechanisms [42]. SAM concentrations are maintained by stimulating the BHMT pathway [43]. Betaine activates BHMT for methionine and SAM formation [44,45]; in contrast, SAM suppresses BHMT expression in order to decrease utilization of betaine as a methyl donor [42,46]. Betaine supplementation in maternal diet downregulated hepatic BHMT gene expression in the weaning piglets, much like a negative feedback loop.

Age-dependent effects perform a critical function on gene expression in the studies of maternal nutritional programming, leading to the varied profiles of gene regulation at different life stages [47-49]. Our studies also showed the different expressions of hepatic genes involved in cholesterol metabolism between newborn [50] and weaning stage of the piglets exposed to maternal betaine diet.

In summary, our findings indicate that maternal dietary betaine supplementation during gestation and lactation modifies hepatic cholesterol metabolic gene expression in weaning piglets through AMPK/LXR-dependent pathway and histone modifications. Changes in hepatic cholesterol metabolism in weaning offspring may carry on to adulthood, causing life-time consequences in cholesterol homeostasis later in adult life, and this should be addressed in future studies.

Acknowledgments: This work was supported by the National Basic Research Program of China (2012CB124703), the Priority Academic Program Development of Jiangsu Higher Education Institutions and the Innovation Project of Jiangsu Province Postgraduate Education (2013CXLX13_292).

Author Contributions: D.C., H.L. and W.M. contributed ideas for experimental design and analyzed biochemical parameters and western blotting data and determined hepatic SAM level. M.Y. S.P. and J.H. performed the 
experiments and measurements of m-RNA abundance, western blotting and most biochemical parameters, analyzed and interpreted the results, and drafted the manuscript. R.Z. contributed to experimental concepts and design, provided scientific direction, analyzed and interpreted the results, and finalized the manuscript. All authors read and approved the final manuscript.

Conflicts of Interest: The authors declare that they have no competing interests.

\section{Abbreviations}

$\begin{array}{ll}\text { AHCY } & \text { S-adenosylhomocysteine hydrolase } \\ \text { AMPK } & \text { AMP-activated protein kinase } \\ \text { Bet } & \text { piglets born to sows supplemented with betaine diets } \\ \text { BHMT } & \text { betaine-homocysteine S-methyltransferase } \\ \text { BW } & \text { body weight } \\ \text { Con } & \text { piglets born to sows supplemented with normal diets } \\ \text { CYP7 } \alpha 1 & \text { cholesterol-7alpha-hydroxylase } \\ \text { CYP27 } \alpha 1 & \text { cholesterol-27alpha-hydroxylase } \\ \text { DNMTs } & \text { DNA methyltransferases } \\ \text { FXR } & \text { farnesoid X receptor } \\ \text { GNMT } & \text { glycine N-methyltransferase } \\ \text { H1 } & \text { histone H1 } \\ \text { H3 } & \text { histone H3 } \\ \text { H3K4me3 } & \text { histone H3 lysine 4 trimethylation } \\ \text { H3K27me3 } & \text { histone H3 lysine 27 trimethylation } \\ \text { HDLR } & \text { high-density lipoprotein receptor } \\ \text { HMGCR } & \text { 3-hydroxy-3-methylglutaryl coenzyme A reductase } \\ \text { LDLR } & \text { low density lipoprotein receptor } \\ \text { LXR } & \text { liver X receptor } \\ \text { Met } & \text { Methionine } \\ \text { NR } & \text { Nuclear receptors } \\ \text { PPAR } \alpha & \text { peroxisome proliferator-activated receptor alpha } \\ \text { SAM } & \text { S-adenosylmethionine } \\ \text { SAH } & \text { S-adenosylhomocysteine } \\ \text { SETD7 } & \text { SET Domain Containing Protein 7 } \\ \text { SR-BI } & \text { scavenger receptor class B type I } \\ \text { Tch } & \text { total cholesterol } \\ \text { TBA } & \text { total bile acids } \\ \text { TMG } & \text { trimethylglycine } \\ & \end{array}$

\section{References}

1. Lever, M.; Slow, S. The clinical significance of betaine, an osmolyte with a key role in methyl group metabolism. Clin. Biochem. 2010, 43, 732-744. [CrossRef] [PubMed]

2. Barak, A.J.; Beckenhauer, H.C.; Badakhsh, S.; Tuma, D.J. The effect of betaine in reversing alcoholic steatosis. Alcohol. Clin. Exp. Res. 1997, 21, 1100-1102. [CrossRef] [PubMed]

3. Graf, D.; Kurz, A.K.; Reinehr, R.; Fischer, R.; Kircheis, G.; Haussinger, D. Prevention of bile acid-induced apoptosis by betaine in rat liver. Hepatology 2002, 36, 829-839. [CrossRef] [PubMed]

4. Ji, C.; Kaplowitz, N. Betaine decreases hyperhomocysteinemia, endoplasmic reticulum stress, and liver injury in alcohol-fed mice. Gastroenterology 2003, 124, 1488-1499. [CrossRef]

5. Li, M.; Reynolds, C.M.; Segovia, S.A.; Gray, C.; Vickers, M.H. Developmental programming of nonalcoholic fatty liver disease: The effect of early life nutrition on susceptibility and disease severity in later life. BioMed Res. Int. 2015, 2015, 437107. [CrossRef] [PubMed]

6. Trapani, L.; Segatto, M.; Pallottini, V. Regulation and deregulation of cholesterol homeostasis: The liver as a metabolic "power station". World J. Hepatol. 2012, 4, 184-190. [CrossRef] [PubMed]

7. Ness, G.C. Physiological feedback regulation of cholesterol biosynthesis: Role of translational control of hepatic HMG-CoA reductase and possible involvement of oxylanosterols. Biochim. Biophys. Acta 2015, 1851, 667-673. [CrossRef] [PubMed]

8. Ma, D.; Liu, T.; Chang, L.; Rui, C.; Xiao, Y.; Li, S.; Hogenesch, J.B.; Chen, Y.E.; Lin, J.D. The liver clock controls cholesterol homeostasis through Trib1 protein-mediated regulation of PCSK9/Low density lipoprotein receptor (LDLR) axis. J. Biol. Chem. 2015, 290, 31003-31012. [CrossRef] [PubMed] 
9. Calabresi, L.; Gomaraschi, M.; Simonelli, S.; Bernini, F.; Franceschini, G. HDL and atherosclerosis: Insights from inherited HDL disorders. Biochim. Biophys. Acta 2015, 1851, 13-18. [CrossRef] [PubMed]

10. Dias, V.; Ribeiro, V. Ethnic differences in the prevalence of polymorphisms in CYP7A1, CYP7B1 and CYP27A1 enzymes involved in cholesterol metabolism. J. Pharm. Bioallied Sci. 2011, 3, 453-459. [CrossRef] [PubMed]

11. Chen, G.; Liang, G.; Ou, J.; Goldstein, J.L.; Brown, M.S. Central role for liver X receptor in insulin-mediated activation of Srebp-1c transcription and stimulation of fatty acid synthesis in liver. Proc. Natl. Acad. Sci. USA 2004, 101, 11245-11250. [CrossRef] [PubMed]

12. Cui, J.Y.; Aleksunes, L.M.; Tanaka, Y.; Fu, Z.D.; Guo, Y.; Guo, G.L.; Lu, H.; Zhong, X.B.; Klaassen, C.D. Bile acids via FXR initiate the expression of major transporters involved in the enterohepatic circulation of bile acids in newborn mice. Am. J. Phys. Gastrointest. Liver Phys. 2012, 302, G979-G996. [CrossRef] [PubMed]

13. Musso, G.; Gambino, R.; Cassader, M. Recent insights into hepatic lipid metabolism in non-alcoholic fatty liver disease (NAFLD). Prog. Lipid Res. 2009, 48, 1-26. [CrossRef] [PubMed]

14. Zhang, L.; Reue, K.; Fong, L.G.; Young, S.G.; Tontonoz, P. Feedback regulation of cholesterol uptake by the LXR-IDOL-LDLR axis. Arterioscler. Thromb. Vasc. Biol. 2012, 32, 2541-2546. [CrossRef] [PubMed]

15. Grefhorst, A.; Oosterveer, M.H.; Brufau, G.; Boesjes, M.; Kuipers, F.; Groen, A.K. Pharmacological LXR activation reduces presence of SR-B1 in liver membranes contributing to LXR-mediated induction of HDL-cholesterol. Atherosclerosis 2012, 222, 382-389. [CrossRef] [PubMed]

16. Lehmann, J.M.; Kliewer, S.A.; Moore, L.B.; Smith-Oliver, T.A.; Oliver, B.B.; Su, J.L.; Sundseth, S.S.; Winegar, D.A.; Blanchard, D.E.; Spencer, T.A.; et al. Activation of the nuclear receptor LXR by oxysterols defines a new hormone response pathway. J. Biol. Chem. 1997, 272, 3137-3140. [CrossRef] [PubMed]

17. Tobin, K.A.; Steineger, H.H.; Alberti, S.; Spydevold, O.; Auwerx, J.; Gustafsson, J.A.; Nebb, H.I. Cross-talk between fatty acid and cholesterol metabolism mediated by liver X receptor-alpha. Mol. Endocrinol. 2000, 14, 741-752. [PubMed]

18. Milona, A.; Owen, B.M.; Van Mil, S.; Dormann, D.; Mataki, C.; Boudjelal, M.; Cairns, W.; Schoonjans, K.; Milligan, S.; Parker, M.; et al. The normal mechanisms of pregnancy-induced liver growth are not maintained in mice lacking the bile acid sensor FXR. Am. J. Phys. Gastrointest. Liver Phys. 2010, 298, G151-G158. [CrossRef] [PubMed]

19. Gadaleta, R.M.; Cariello, M.; Sabba, C.; Moschetta, A. Tissue-specific actions of FXR in metabolism and cancer. Biochim. Biophys. Acta 2015, 1851, 30-39. [CrossRef] [PubMed]

20. Williams, K.T.; Schalinske, K.L. Homocysteine metabolism and its relation to health and disease. BioFactors 2010, 36, 19-24. [CrossRef] [PubMed]

21. Finkelstein, J.D. Metabolic regulatory properties of $S$-adenosylmethionine and $S$-adenosylhomocysteine. Clin. Chem. Lab. Med. 2007, 45, 1694-1699. [CrossRef] [PubMed]

22. Caudill, M.A.; Wang, J.C.; Melnyk, S.; Pogribny, I.P.; Jernigan, S.; Collins, M.D.; Santos-Guzman, J.; Swendseid, M.E.; Cogger, E.A.; James, S.J. Intracellular S-adenosylhomocysteine concentrations predict global DNA hypomethylation in tissues of methyl-deficient cystathionine beta-synthase heterozygous mice. J. Nutr. 2001, 131, 2811-2818. [PubMed]

23. Yang, J.; Craddock, L.; Hong, S.; Liu, Z.M. Amp-activated protein kinase suppresses LXR-dependent sterol regulatory element-binding protein-1c transcription in rat hepatoma MCA-RH7777 cells. J. Cell. Biochem. 2009, 106, 414-426. [CrossRef] [PubMed]

24. Dahlhoff, C.; Worsch, S.; Sailer, M.; Hummel, B.A.; Fiamoncini, J.; Uebel, K.; Obeid, R.; Scherling, C.; Geisel, J.; Bader, B.L.; et al. Methyl-donor supplementation in obese mice prevents the progression of NAFLD, activates AMPK and decreases acyl-carnitine levels. Mol. Metab. 2014, 3, 565-580. [CrossRef] [PubMed]

25. Liu, X.; Wang, J.; Li, R.; Yang, X.; Sun, Q.; Albrecht, E.; Zhao, R. Maternal dietary protein affects transcriptional regulation of myostatin gene distinctively at weaning and finishing stages in skeletal muscle of meishan pigs. Epigenetics 2011, 6, 899-907. [CrossRef] [PubMed]

26. Molloy, A.M.; Mills, J.L.; Cox, C.; Daly, S.F.; Conley, M.; Brody, L.C.; Kirke, P.N.; Scott, J.M.; Ueland, P.M. Choline and homocysteine interrelations in umbilical cord and maternal plasma at delivery. Am. J. Clin. Nutr. 2005, 82, 836-842. [PubMed]

27. Ramis, G.; Evangelista, J.N.B.; Quereda, J.J.; Pallares, F.J.; de la Fuente, J.M.; Munoz, A. Use of betaine in gilts and sows during lactation: Effects on milk quality, reproductive parameters, and piglet performance. J. Swine Health Prod. 2011, 19, 226-232. 
28. Dominguez-Salas, P.; Moore, S.E.; Cole, D.; da Costa, K.A.; Cox, S.E.; Dyer, R.A.; Fulford, A.J.; Innis, S.M.; Waterland, R.A.; Zeisel, S.H.; et al. DNA methylation potential: Dietary intake and blood concentrations of one-carbon metabolites and cofactors in rural african women. Am. J. Clin. Nutr. 2013, 97, 1217-1227. [CrossRef] [PubMed]

29. Storch, K.J.; Wagner, D.A.; Young, V.R. Methionine kinetics in adult men: Effects of dietary betaine on 1-[2h3-methyl-1-13c]methionine. Am. J. Clin. Nutr. 1991, 54, 386-394. [PubMed]

30. McGregor, D.O.; Dellow, W.J.; Robson, R.A.; Lever, M.; George, P.M.; Chambers, S.T. Betaine supplementation decreases post-methionine hyperhomocysteinemia in chronic renal failure. Kidney Int. 2002, 61, 1040-1046. [CrossRef] [PubMed]

31. Schwab, U.; Torronen, A.; Toppinen, L.; Alfthan, G.; Saarinen, M.; Aro, A.; Uusitupa, M. Betaine supplementation decreases plasma homocysteine concentrations but does not affect body weight, body composition, or resting energy expenditure in human subjects. Am. J. Clin. Nutr. 2002, 76, 961-967. [PubMed]

32. Yang, H.S.; Lee, J.I.; Joo, S.T.; Park, G.B. Effects of dietary glycine betaine on growth and pork quality of finishing pigs. Asian Australas. J. Anim. Sci. 2009, 22, 706-711. [CrossRef]

33. Ross, A.B.; Bruce, S.J.; Blondel-Lubrano, A.; Oguey-Araymon, S.; Beaumont, M.; Bourgeois, A.; Nielsen-Moennoz, C.; Vigo, M.; Fay, L.B.; Kochhar, S.; et al. A whole-grain cereal-rich diet increases plasma betaine, and tends to decrease total and ldl-cholesterol compared with a refined-grain diet in healthy subjects. Br. J. Nutr. 2011, 105, 1492-1502. [CrossRef] [PubMed]

34. Hu, Y.; Sun, Q.; Li, X.; Wang, M.; Cai, D.; Zhao, R. In ovo injection of betaine affects hepatic cholesterol metabolism through epigenetic gene regulation in newly hatched chicks. PLoS ONE 2015, 10, e0122643. [CrossRef] [PubMed]

35. Li, G.; Guo, G.L. Farnesoid X receptor, the bile acid sensing nuclear receptor, in liver regeneration. Acta Pharm. Sin. B 2015, 5, 93-98. [CrossRef] [PubMed]

36. Gupta, S.; Pandak, W.M.; Hylemon, P.B. LXR alpha is the dominant regulator of CYP7A1 transcription. Biochem. Biophys. Res. Commun. 2002, 293, 338-343. [CrossRef]

37. Deminice, R.; da Silva, R.P.; Lamarre, S.G.; Kelly, K.B.; Jacobs, R.L.; Brosnan, M.E.; Brosnan, J.T. Betaine supplementation prevents fatty liver induced by a high-fat diet: Effects on one-carbon metabolism. Amino Acids 2015, 47, 839-846. [CrossRef] [PubMed]

38. Meier, J.L. Metabolic mechanisms of epigenetic regulation. ACS Chem. Biol. 2013, 8, 2607-2621. [CrossRef] [PubMed]

39. Medici, V.; Shibata, N.M.; Kharbanda, K.K.; LaSalle, J.M.; Woods, R.; Liu, S.; Engelberg, J.A.; Devaraj, S.; Torok, N.J.; Jiang, J.X.; et al. Wilson's disease: Changes in methionine metabolism and inflammation affect global DNA methylation in early liver disease. Hepatology 2013, 57, 555-565. [CrossRef] [PubMed]

40. Wagner, T.; Jung, M. New lysine methyltransferase drug targets in cancer. Nat. Biotechnol. 2012, 30, $622-623$. [CrossRef] [PubMed]

41. Cai, D.; Jia, Y.; Song, H.; Sui, S.; Lu, J.; Jiang, Z.; Zhao, R. Betaine supplementation in maternal diet modulates the epigenetic regulation of hepatic gluconeogenic genes in neonatal piglets. PLoS ONE 2014, 9, e105504. [CrossRef] [PubMed]

42. Obeid, R. The metabolic burden of methyl donor deficiency with focus on the betaine homocysteine methyltransferase pathway. Nutrients 2013, 5, 3481-3495. [CrossRef] [PubMed]

43. Jacobs, R.L.; Stead, L.M.; Devlin, C.; Tabas, I.; Brosnan, M.E.; Brosnan, J.T.; Vance, D.E. Physiological regulation of phospholipid methylation alters plasma homocysteine in mice. J. Biol. Chem. 2005, 280, 28299-28305. [CrossRef] [PubMed]

44. Park, E.I.; Garrow, T.A. Interaction between dietary methionine and methyl donor intake on rat liver betaine-homocysteine methyltransferase gene expression and organization of the human gene. J. Biol. Chem. 1999, 274, 7816-7824. [CrossRef] [PubMed]

45. Purohit, V.; Abdelmalek, M.F.; Barve, S.; Benevenga, N.J.; Halsted, C.H.; Kaplowitz, N.; Kharbanda, K.K.; Liu, Q.Y.; Lu, S.C.; McClain, C.J.; et al. Role of S-adenosylmethionine, folate, and betaine in the treatment of alcoholic liver disease: Summary of a symposium. Am. J. Clin. Nutr. 2007, 86, 14-24. [PubMed]

46. Finkelstein, J.D.; Harris, B.J.; Kyle, W.E. Methionine metabolism in mammals: Kinetic study of betaine-homocysteine methyltransferase. Arch. Biochem. Biophys. 1972, 153, 320-324. [CrossRef] 
47. Laker, R.C.; Lillard, T.S.; Okutsu, M.; Zhang, M.; Hoehn, K.L.; Connelly, J.J.; Yan, Z. Exercise prevents maternal high-fat diet-induced hypermethylation of the Pgc-1alpha gene and age-dependent metabolic dysfunction in the offspring. Diabetes 2014, 63, 1605-1611. [CrossRef] [PubMed]

48. Gugusheff, J.R.; Bae, S.E.; Rao, A.; Clarke, I.J.; Poston, L.; Taylor, P.D.; Coen, C.W.; Muhlhausler, B.S. Sex and age-dependent effects of a maternal junk food diet on the mu-opioid receptor in rat offspring. Behav. Brain Res. 2016, 301, 124-131. [CrossRef] [PubMed]

49. Kwekel, J.C.; Desai, V.G.; Moland, C.L.; Branham, W.S.; Fuscoe, J.C. Age and sex dependent changes in liver gene expression during the life cycle of the rat. BMC Genom. 2010, 11. [CrossRef] [PubMed]

50. Cai, D.; Jia, Y.; Lu, J.; Yuan, M.; Sui, S.; Song, H.; Zhao, R. Maternal dietary betaine supplementation modifies hepatic expression of cholesterol metabolic genes via epigenetic mechanisms in newborn piglets. Br. J. Nutr. 2014, 112, 1459-1468. [CrossRef] [PubMed]

(c) 2016 by the authors; licensee MDPI, Basel, Switzerland. This article is an open access article distributed under the terms and conditions of the Creative Commons Attribution (CC-BY) license (http://creativecommons.org/licenses/by/4.0/). 